\title{
PERANCANGAN APLIKASI PENGELOLAAN DOKUMEN DAN SIMULASI PENILAIAN AKREDITASI DI PRODI S1 SISTEM INFORMASI UNIVERSITAS TELKOM
}

\section{THE DESIGN OF DOCUMENT MANAGEMENT AND ACCREDITATION SCORING SIMULATION APPLICATION FOR INFORMATION SYSTEM DEPARTMENT TELKOM UNIVERSITY}

\author{
${ }^{1}$ Riza Agustiansyah, ${ }^{2}$ Kiswanto, ${ }^{3}$ Tien Fabrianti Kusumasari \\ 1,2,3Program Studi Sistem Informasi, Fakultas Rekayasa Industri, Telkom University \\ 'riza.agustiansyah@gmail.com, ${ }^{2}$ kiswanto1996@gmail.com, ${ }^{3}$ tienkusumasari@telkomuniversity.ac.id
}

\begin{abstract}
Abstrak - Program Studi (prodi) Sistem Informasi (SI) Universitas Telkom secara berkala melakukan proses persiapan akreditasi program studi untuk persiapan evaluasi yang dilakukan oleh Badan Akreditasi Nasional Perguruan Tinggi (BAN-PT). Proses persiapan akreditasi yang dilakukan oleh prodi SI saat ini secara umum tidak berbeda dengan prodi-prodi lain di Indonesia, yaitu mulai dari pembentukan tim persiapan akreditasi, pengumpulan dokumen-dokumen terkait akreditasi, serta simulasi penilaian yang dilakukan dengan menginput komponen penilaian satu persatu kedalam aplikasi pengolah data yang umum digunakan di Indonesia yaitu Microsoft Excel. Karena proses pengumpulan dan pengolahan data ini dilakukan hanya menjelang saat akreditasi, menyebabkan proses pengumpulan data maupun dokumen menjadi sulit dan membutuhkan sumber daya yang banyak baik dari sisi tenaga, waktu dan biaya. Untuk mengatasi permasalahan yang terjadi pada saat akreditasi, pada penelitian ini dibuat aplikasi pengelolaan dokumen dan penilaian akreditasi. Untuk tahap awal, aplikasi dibuat dalam ruang lingkup Borang Akreditasi Standar 5 yang membahas mengenai kurikulum, pembelajaran, dan suasana akademik. Bagian ini dipilih karena meliputi banyak dokumen dan penilaian komponen akreditasi sehingga apabila berhasil dapat diterapkan untuk akreditasi secara keseluruhan. Aplikasi dibuat untuk pengelolaan tim akreditasi, pengelolaan dokumen sampai menghasilkan laporan Borang serta melakukan simulasi penilaian akreditasi. Metode yang digunakan pada perancangan sistem menggunakan metode waterfall karena kebutuhan sistem dianggap sudah jelas. Dari hasil perancangan aplikasi yang dilakukan pada penelitian ini diperoleh peningkatan efisiensi sebesar 54\% yang didapat dari jumlah aktivitas dari proses bisnis akreditasi standar 5 yang menggunakan aplikasi dibagi dengan jumlah total aktivitas. Selain peningkatan efisiensi, dengan menggunakan aplikasi ini dicapai peningkatan efektivitas sebesar 34\% yang didapat dari jumlah penilaian otomatis yang dilakukan oleh sistem dibagi dengan jumlah seluruh penilaian komponen akreditasi standar 5 .
\end{abstract}

Kata kunci: Aplikasi Akreditasi, Aplikasi Pengelolaan Dokumen Akreditasi, Aplikasi Simulasi Penilaian Akreditasi, Simulasi Penilaian Akreditasi, Simulasi Akreditasi, Akreditasi Program Studi S1, Aplikasi Pengelolaan Dokumen

Abstract-Information System Department Telkom University, regularly
process the accreditation preparation program for the preparation of the
evaluation conducted by the national accreditation agency for higher
education (BAN-PT). The current process of accreditation preparation process conducted by Information System Department Telkom University more or less is still similar to what was done by other institutions in Indonesia, namely starting from the formation of the preparation team for accreditation, the collection of related accreditation documents are scattered in units at the University, as well as simulation assessment conducted by the assessment component input one by one into spreadsheet applications that are commonly used in Indonesia that is Microsoft Excel. Because the process of collecting and processing of these data is done only towards the time of accreditation, this condition causes the process of collecting data as well as documents to be difficult and requires a lot of resources from the side of the effort, time and cost. To resolve problems that occur at the time of accreditation, this application is made to do document management and scoring simulation of accreditation. For the initial stage, the application is created in the scope of theAccreditation Standard 5 which discusses about the curriculum, learning, and academic atmosphere. This section was chosen because it includes many documents and assessment components of accreditation so that if successful could apply to whole accreditation standard. Applications are made to the management of the accreditation team, document management to produce the report Form and perform simulated assessment accreditation. The methods used in the design of system using method of waterfall because the system requirements are considered fix. From the results of the design of the application on this research obtained increased efficiency of $54 \%$ which calculated from the amount of activity from the accreditation standard 5 business processes that use applications divided by the total amount of activity. In addition to increasing efficiency, by using this application also achieved an increase in the effectiveness of $34 \%$ which calculate from the total number of automated assessment carried out by the system divided by total amount of all assessment components of accreditation standard 5 .

Keywords: Accreditation Application, Document Management Application for Accreditation, Accreditation Scoring Simulation Application, Accreditation Scoring Simulation, Accreditation for Under Graduated Department, Document Management Application

\section{PENDAHULUAN}

Berdasarkan PERMENRISTEKDIKTI No. 32 Tahun 2016, desinisi Akreditasi adalah kegiatan penilaian untuk menentukan kelayakan Program Studi dan Perguruan Tinggi. Tujuan dari Akreditasi adalah menentukan kelayakan Program Studi dan 
Perguruan Tinggi berdasarkan kriteria yang mengacu pada Standar Nasional Pendidikan Tinggi; dan menjamin mutu Program Studi dan Perguruan Tinggi secara eksternal baik bidang akademik maupun non akademik untuk melindungi kepentingan mahasiswa dan masyarakat [1].

Program Studi (prodi) Sistem Informasi (SI) Universitas Telkom secara berkala melakukan proses persiapan akreditasi program studi untuk persiapan evaluasi yang dilakukan oleh Badan Akreditasi Nasional Perguruan Tinggi (BAN-PT). Proses persiapan akreditasi yang dilakukan oleh prodi SI saat ini kurang lebih masih sama dengan apa yang dilakukan oleh prodi-prodi lain di Indonesia, yaitu mulai dari pembentukan tim persiapan akreditasi, pengumpulan dokumen-dokumen terkait akreditasi yang tersebar pada unit- unit di Universitas, serta simulasi penilaian yang dilakukan dengan menginput komponen penilaian satu persatu kedalam aplikasi pengolah data yang umum digunakan di Indonesia yaitu Microsoft Excel. Karena proses pengumpulan dan pengolahan data ini dilakukan hanya menjelang saat akreditasi, kondisi ini menyebabkan proses pengumpulan data maupun dokumen menjadi sulit dan membutuhkan sumber daya yang banyak baik dari sisi tenaga, waktu dan biaya. Tidak terdapat keterangan yang lengkap tentang kebutuhan format dokumen yang diperlukan dalam proses akreditasi. Selain itu tidak ada penjelasan rinci mengenai tugas untuk setiap anggota tim persiapan akreditasi sehingga sulit untuk memantau proses persiapan akreditasi.

Untuk mengatasi permasalahan yang terjadi pada saat akreditasi, pada penelitian ini dibuat aplikasi pengelolaan dokumen dan penilaian akreditasi. Untuk tahap awal, aplikasi dibuat dalam ruang lingkup Borang Akreditasi Standar 5 yang membahas mengenai kurikulum, pembelajaran, dan suasana akademik. Bagian ini dipilih karena meliputi banyak dokumen dan penilaian komponen akreditasi sehingga apabila berhasil dapat diterapkan untuk akreditasi secara keseluruhan. Aplikasi dibuat untuk pengelolaan tim akreditasi, pengelolaan dokumen sampai menghasilkan laporan Borang serta melakukan simulasi penilaian akreditasi. Metode yang digunakan pada perancangan sistem menggunakan metode waterfall karena kebutuhan sistem dianggap sudah jelas sejak awal.

Untuk mengukur keberhasilan dari pembuatan aplikasi akreditasi ini, pada perancangan ini dilakukan perhitungan peningkatan efisiensi dan efektivitas proses bisnis. Perhitungan peningkatan efisiensi dihitung dari jumlah aktivitas dari proses bisnis akreditasi standar 5 yang menggunakan aplikasi dibagi dengan jumlah total aktivitas. Sementara itu peningkatan efektivitas dihitung dari jumlah penilaian otomatis yang dilakukan oleh sistem dibagi dengan jumlah seluruh penilaian komponen akreditasi standar 5.

\section{STUDILITERATUR}

\section{A. Akreditasi}

Akreditasi dilakukan oleh BAN-PT atas dasar kriteria yang bersifat terbuka. Akreditasi merupakan proses yang dilakukan untuk menentukan kelayakan program dan satuan pendidikan pada jalur pendidikan formal dan nonformal setiap jenjang dan jenis pendidikan. Keputusan mengenai mutu didasarkan pada evaluasi dan penilaian terhadap berbagai bukti yang terkait dengan standar yang ditetapkan. Adapun tujuan dan manfaat akreditasi program studi adalah memberi jaminan bahwa program studi yang terakreditasi telah memenuhi standar mutu yang ditetapkan, mendorong program studi untuk terus menerus melakukan perbaikan dan mempertahankan mutu yang tinggi, dan hasil akreditasi dapat dimanfaatkan sebagai dasar pertimbangan dalam transfer kredit perguruan tinggi, pemberian bantuan dan alokasi dana, serta pengakuan dari badan atau instansi yang lain.Sedangkan aspek yang perlu diperhatikan dalam pelaksanaan akreditasi program studi yaitu, standar akreditasi, prosedur akreditasi, instrument akreditasi dan kode etik akreditasi. Terdapat 7 standar yang menjelaskan komitmen program studi sarjana terhadap kapasitas institusional dan komitmen terhadap efektivitas program pendidikan. Standar akreditasi tersebut antara lain;

- Standar 1. Visi, misi, tujuan dan sasaran, serta strategi pencapaian

- Standar 2. Tata pamong, kepemimpinan, sistem pengelolaan, dan penjaminan mutu

- Standar 3. Mahasiswa dan lulusan

- Standar 4. Sumber daya manusia

- Standar 5. Kurikulum, pembelajaran, dan suasana akademik

- Standar 6. Pembiayaan, sarana dan prasarana, serta sistem informasi

- Standar 7. Penelitian dan pelayanan/pengabdian kepada masyarakat, dan kerja sama

Penilaian kriteria tersebut dinilai dari 3 instrumen, yaitu Borang Program Studi, Evaluasi Diri Program Studi, dan Borang yang diisi oleh Fakultas/ Sekolah Tinggi. Instrumen akreditasi dinilai kualitatif dan kuantitatif. Untuk menetapkan peringkat akreditasi, maka penilaian kualitatif dibuat menjadi skor kuantitatif dengan rincian sebagai berikut: Skor 4 (Sangat Baik), jika semua kinerja mutu setiap standar atau elemen yang diukur sangat baik.. Skor 3 (Baik), jika semua kinerja mutu setiap standar atau elemen yang diukur baik dan tidak ada kekurangan yang berarti. Skor 2 (Cukup), jika semua kinerja mutu setiap standar atau elemen yang diukur cukup, namun tidak ada yang menonjol. Skor 1 (Kurang), jika semua kinerja mutu setiap standar atau elemen yang diukur kurang. Skor 0 (Sangat Kurang), jika semua kinerja mutu setiap standar atau elemen yang diukur sangat kurang atau tidak ada.

Hasil akhir penilaian instrument akan menghasilkan pernyataan Program Studi tersebut Terakreditasi atau Tidak Terkreditasi. Peringkat bagi Program Studi yang dinyatakan Terakreditasi yaitu: A (Sangat Baik), B (Baik), C (Cukup), dan Tidak Terakreditasi[2].

\section{B. Riset Sebelumnya}

Pada riset sebelumnya telah dilakukan penelitian tentang pembuatan perancangan perangkat lunak borang akreditasi program studi oleh Ahmad Fauzi, M.Kom pada tahun 2012. Pada penelitian ini dibuat aplikasi berupa website untuk akreditasi program studi sarjana pada standar kurikulum dan pembelajaran. Pembuatan aplikasi didasari karena data kinerja program studi yang tidak terdokumentasi dengan baik menyebabkan pengisian borang akreditasi program studi selalu akan menjadi kegiatan baru karena tidak tersedianya dokumentasi yang efektif atas semua kegiatan yang dilakukan oleh program studi [3].

Selain itu juga terdapat riset tentang pembuatan rancang bangun perangkat lunak sistem kemahasiswaan dan alumni untuk pengembangan sistem informasi terintegrasi sesuai kebutuhan 
pengisian borang akreditasi BAN-PT pada jurusan Sistem Informasi ITS oleh Faturrahman, Sholiq dan Feby Artwodini Muqtadiroh pada tahun 2013. Pada penelitian ini dibuat aplikasi untuk menunjang akreditasi program studi sarjana. Pembuatan aplikasi berfokus pada hal yang terkait dengan kemahasiswaan dan alumni. Sistem ini dibuat karena saat ini pendokumentasiaanya masih belum baik dan terpisah - pisah [4]. Penelitian lain terkait akreditasi dilakukan oleh Fandi Cahyo Saputro, Wiwik Anggraeni dan Ahmad Mukhlason. Penelitian dilakukan pada proses evaluasi diri apakah program studi atau perguruan tinggi sudah memenuhi standar yang ditetapkan oleh BAN-PT. Dalam melaksanakan proses evaluasi diri, diperlukan sumber data yang digunakan sebagai dasar dalam menilai pada suatu kriteria. Pada kebanyakan program studi, semua data tersebar pada sistem informasi dan dokumen fisik yang berbeda sehingga membutuhkan waktu dan usaha yang lebih untuk mengintegrasikan hingga menilainya. Pada penelitian dari paper ini dilakukan pembuatan sistem yang mampu mengambil dan menampilkan hasil evaluasi secara visual secara otomatis dengan lebih hemat waktu dan usaha. Sistem dibuat dalam bentuk dashboard. Melalui dashboard, pihak internal program studi dapat mengetahui posisi penilaian mereka pada periode tertentu dan mampu memperbaikinya jika kurang dari target yang ditetapkan oleh standar. Hasil luaran dari artikel ini adalah telaah dari proses pembuatan dashboard yang dapat digunakan untuk mengevaluasi keadaan internal program studi atau perguruan tinggi sesuai dengan penilaian berdasarkan standar BAN. [5]

\section{METODOLOGI PENELITIAN}

Metodologi penelitian yang digunakan pada penelitian ini adalah Metode Waterfall. Metode waterfall cocok digunakan pada rancang bangun seuatu sistem yang baru (bukan modifikasi sistem), dimana requirement atau kebutuhan sistem telah didefinisikan dengan jelas [6].Tahap-tahap dari metode waterfall dapat dilihat pada gambar 1. Sistematika penelitian merupakan langkah-langkah yang dilakukan dalam penelitian. Gambar 2. menampilkan sistematika penelitian untuk pembuatan aplikasi akreditasi program studi dengan menerapkan metode pengembangan aplikasi waterfall pada tahap pengembangan aplikasi.

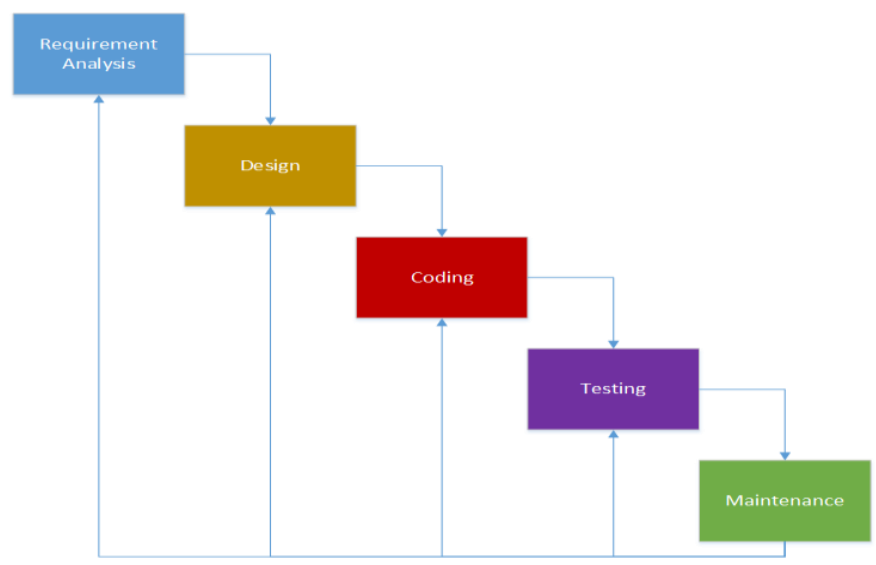

Gambar 1. Tahapan Metode Waterfall [6]
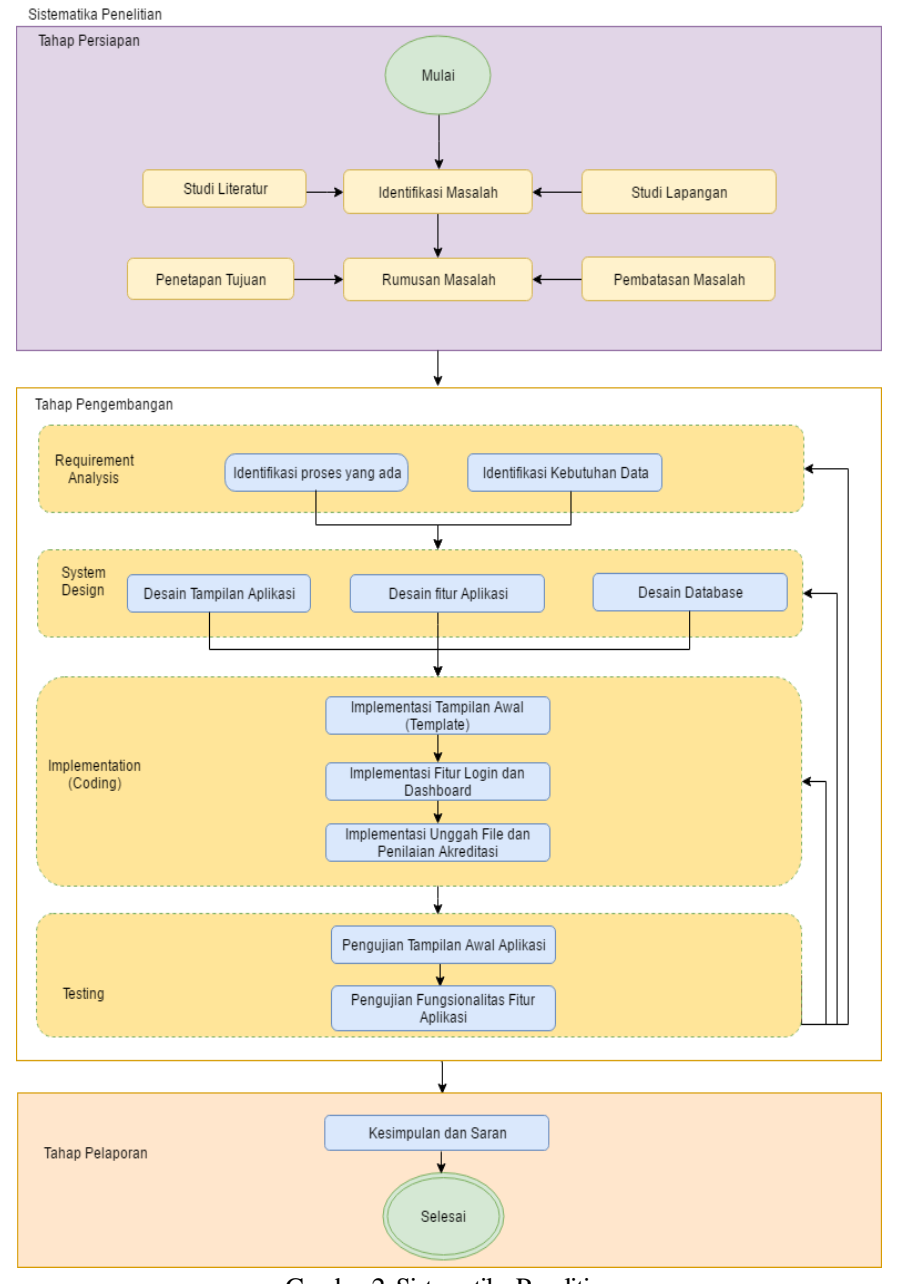

Gambar 2. Sistematika Penelitian

\section{HASIL DAN ANALISIS}

A. Proses Bisnis

Pada penelitian ini difokuskan pada bidang akreditasi program studi, khususnya pada standar 5 untuk program studi S1 Sistem Informasi, Universitas Telkom. Maka dari itu proses bisnis yang dijelaskan yaitu proses bisnis persiapan akreditasi pada program studi Sistem Informasi, Universitas Telkom. Tujuan penggunaan proses bisnis agar memudahkan dalam melakukan analisa kebutuhan user sehingga dapat mengoptimalkan proses bisnis. Proses bisnis existing persiapan akreditasi prodi SI dapat dilihat pada Gambar 3.

Pada gambar 4 digambarkan proses bisnis usulan yang telah dilakukan pengembangan dengan penambahan aplikasi dalam melakukan beberapa aktivitas. Aktivitas yang diwarnai merupakan aktivitas yang dilakukan menggunakan sistem informasi. Jumlah aktivitas yang dilakukan menggunakan sistem informasi atau aplikasi berjumlah 6 dari seluruh aktivitas yang berjumlah 11 .

B. Analisis Kebutuhan Aplikasi

Hasil analisis berdasarkan kebutuhan tersebut maka diperlukan sebuah aplikasi persiapan akreditasi yang memiliki fitur utama sebagai yang dapat dilihat pada Tabel I. 


\section{Use Case Diagram}

Use case diagram merupakan sebuah diagram yang digunakan untuk menggambarkan fungsionalitas aplikasi dari masing-masing user yang menggunakan aplikasi. Pada Gambar 5 digambarkan use case diagram untuk pengelolaan user. Use case diagram ini menjelaskan fungsionalitas yang dimiliki oleh admin untuk melakukan pengelolaan user aplikasi. Lebih lanjut, pada Gambar 6 digambarkan mengenai use case diagram untuk pengelolaan dokumen. Pegelolaan dokumen dapat dilakukan oleh admin, kaprodi, tim pengumpul data standar 5 maupun tim pengumpul data akreditasi, namun masing-masing aktor memiliki fungsionalitas yang berbeda.

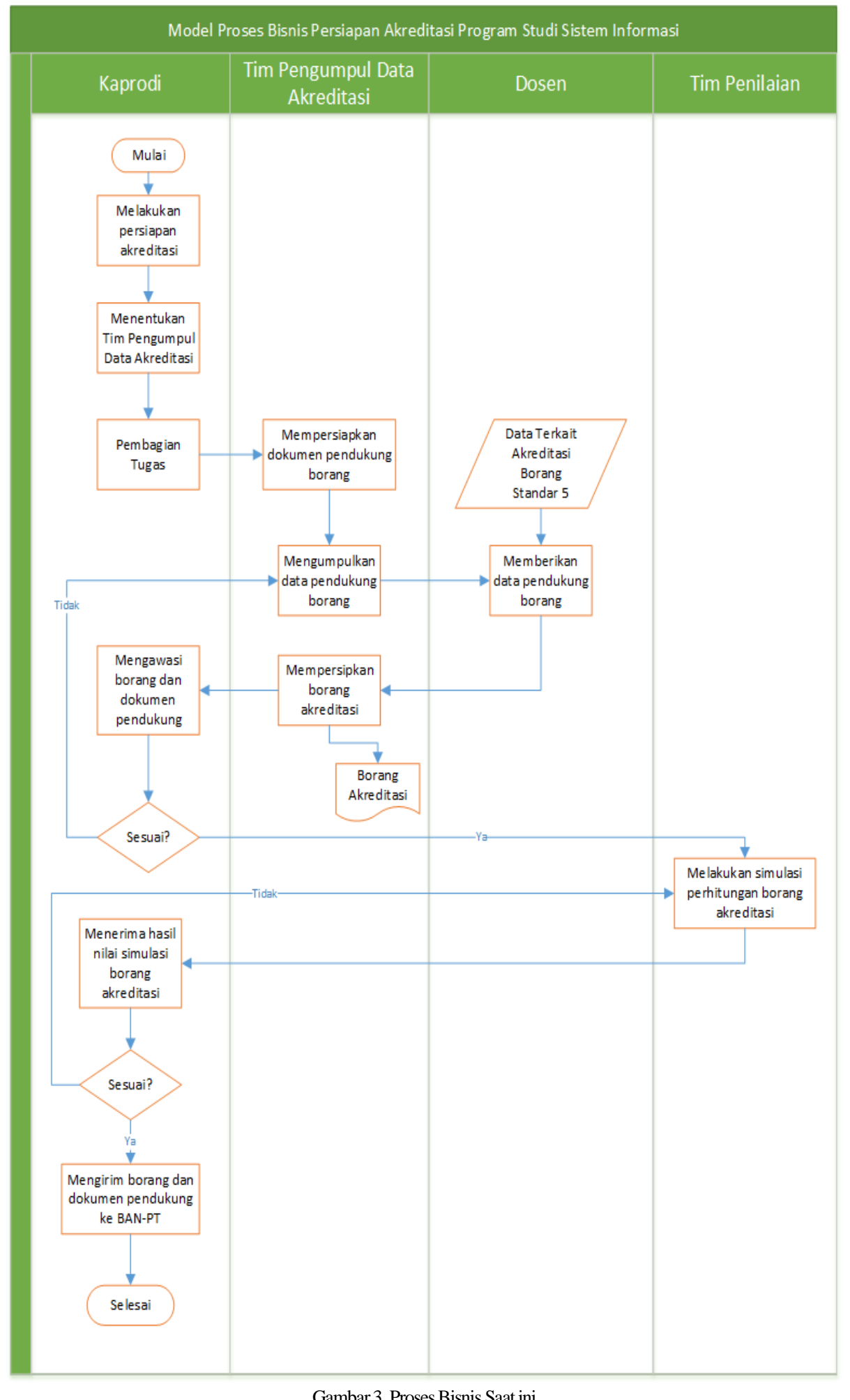




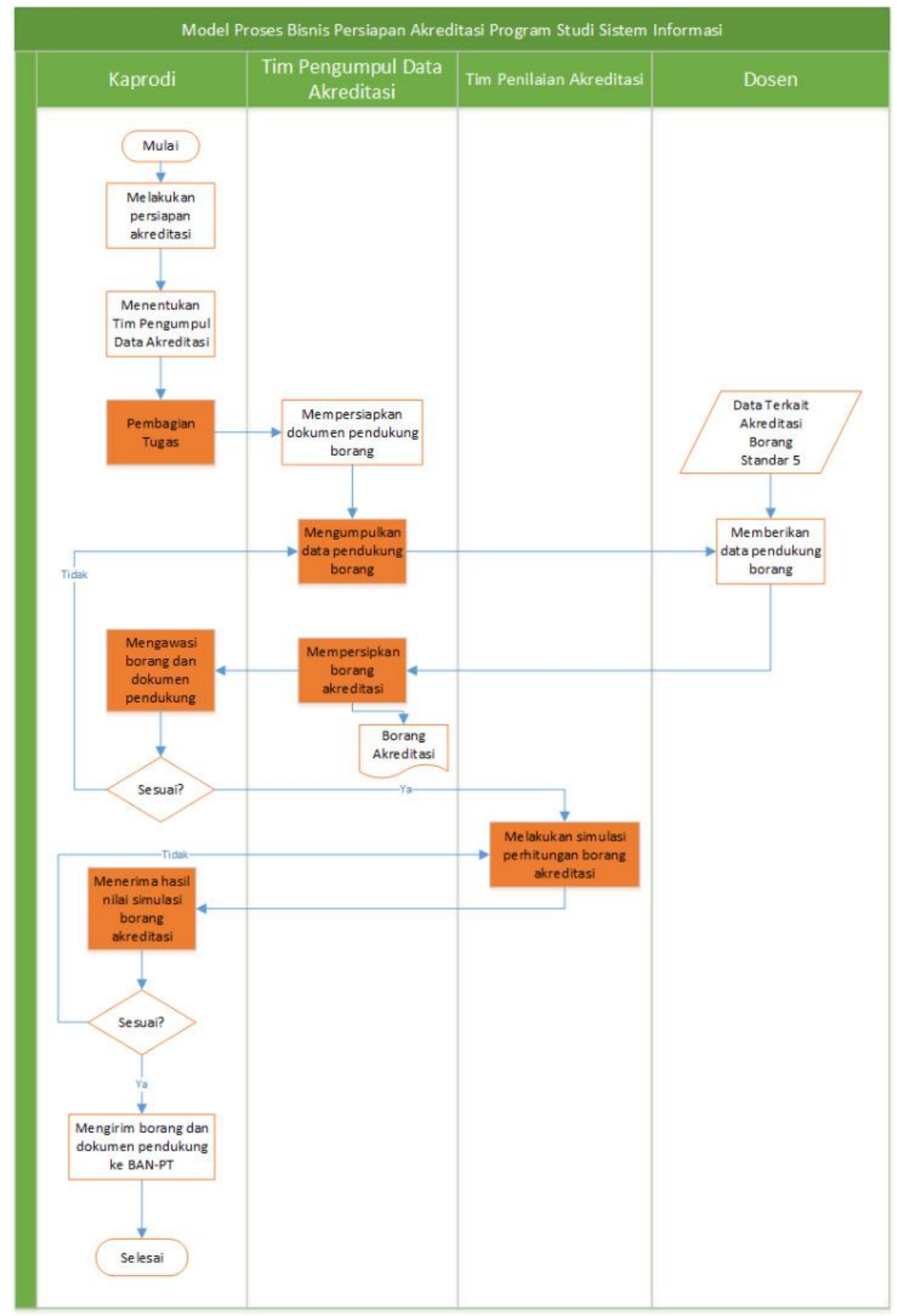

Gambar 4. Proses Bisnis Usulan

\section{A. Class Diagram}

Class diagram menggambarkan jenis objek yang terdapat pada sistem dan hubungan antar objek tersebut [7]. Pada Gambar 8 diilustrasikan mengenai hubungan antar class pada aplikasi. Terdapat 6 controller yakni Profil, Login, Timakreditasi, Logout, Dashboard, Standar5. Setiap controller memiliki hubungan extend ke class CI_Controller. Kemudian terdapat 3 model, yakni Users_model, Standar5_model dan File_model. Setiap model memiliki hubungan extend ke class CI_Model. Setiap controller menggunakan hubungan dependency ke tiap model, dikarenakan untuk menjalankan method controller, diperlukan method pada model.

\section{B. Sequence Diagram}

Sequence diagram menggambarkan interaksi panggilan antar objek pada tingkat yang lebih detail. Panggilan yang berbeda dilakukan untuk objek yang berbeda. Sequence diagram memiliki dua bagian. Bagian vertikal menunjukkan urutan pesan dalam urutan waktu kejadiannya, sedangkan urutan horizontal menunjukkan objek dimana pesan dikirim [8]. User memilih fungsi kurikulum (submenu) / pembelajaran (submenu) dan fungsi get_data untuk menampilkan halaman data dan dokumen standar 5. Jika dokumen ada dan sesuai format yang ditentukan maka memanggil fungsi uploaddokumen_excel, serta memanggil upload_data pada library PHP_Excel untuk membaca data yang diunggah dan memasukannya 
ke dalam basis data melalui fungsi upload_excel. Terdapat 2 alternatif berdasarkan keberhasilan pengunggahan, dimana controller akan memanggil fungsi set_flashdata(message) untuk menyimpan pesan bahwa pengunggahan gagal atau berhasil.

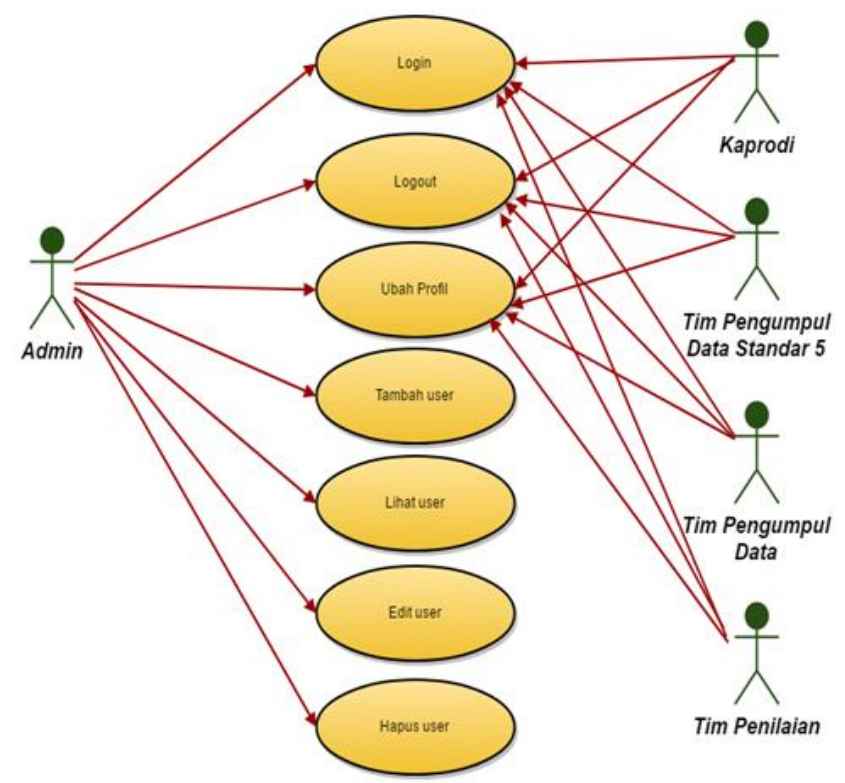

Gambar 5. Use Case Diagram Pengelolaan User

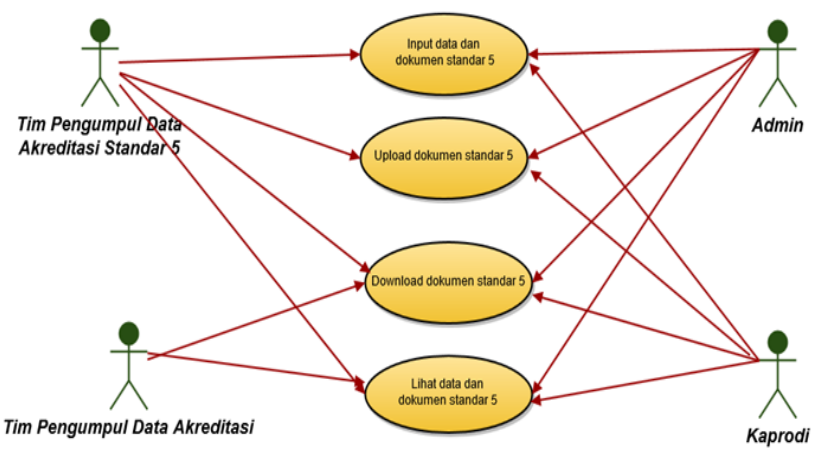

Gambar 6. User Use Case Diagram Pengelolaan Dokumen

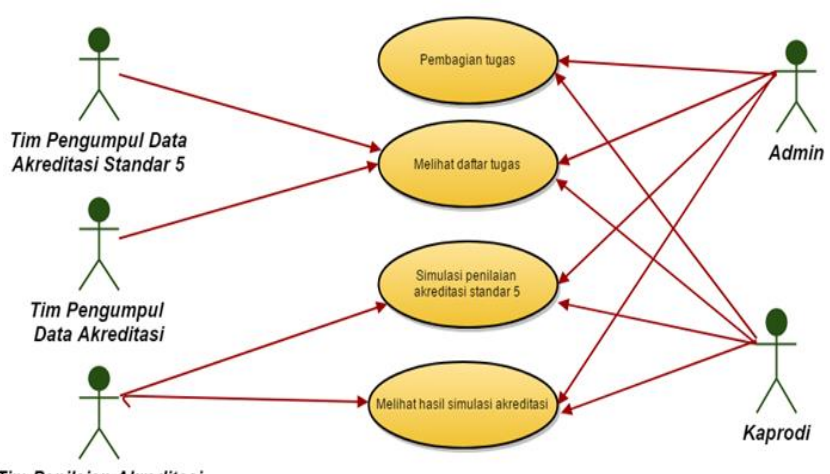

Tim Penilaian Akreditasi

Gambar 7. User Use Case Diagram Simulasi Penilaian Akreditasi
TABEL I.

KEBUTUHAN APLIKAS

\begin{tabular}{|c|c|c|c|}
\hline No & Fitur & Deskripsi & User \\
\hline 1. & $\begin{array}{l}\text { List file } \\
\text { kebutuhan } \\
\text { akreditasi }\end{array}$ & $\begin{array}{l}\text { Menampilkan data dan } \\
\text { dokumen apa yang } \\
\text { diperlukan dalam pengisian } \\
\text { borang akreditasi, serta } \\
\text { ditampilkan deskripsi dan } \\
\text { jenis filenya. }\end{array}$ & $\begin{array}{l}\text { Admin, Kaprodi, } \\
\text { Tim Pengumpul } \\
\text { Data Akreditasi }\end{array}$ \\
\hline 2. & $\begin{array}{c}\text { Upload } \\
\text { dokumen }\end{array}$ & $\begin{array}{l}\text { Mengunggah dokumen } \\
\text { yang diperlukan untuk } \\
\text { keperluan akreditasi. Pada } \\
\text { fitur ini terdapat deskripsi } \\
\text { yang digunakan untuk } \\
\text { menjelaskan file yang } \\
\text { diunggah tersebut. }\end{array}$ & $\begin{array}{l}\text { Admin, Kaprodi, } \\
\text { Tim Pengumpul } \\
\text { Data Akreditasi } \\
\text { Standar } 5\end{array}$ \\
\hline 3. & $\begin{array}{c}\text { Download } \\
\text { dokumen }\end{array}$ & $\begin{array}{l}\text { Mengunduh dokumen yang } \\
\text { sudah terunggah dalam } \\
\text { sistem untuk keperluan } \\
\text { dokumen hardcopy. }\end{array}$ & $\begin{array}{l}\text { Admin, Kaprodi, } \\
\text { Tim Pengumpul } \\
\text { Data Akreditasi }\end{array}$ \\
\hline 4. & $\begin{array}{l}\text { Melihat } \\
\text { dokumen }\end{array}$ & $\begin{array}{l}\text { Melihat dokumen yang } \\
\text { sudah terunggah dalam } \\
\text { sistem. Namun hanya file } \\
\text { yang memiliki ekstensi .pdf }\end{array}$ & $\begin{array}{l}\text { Admin, Kaprodi, } \\
\text { Tim Pengumpul } \\
\text { Data Akreditasi }\end{array}$ \\
\hline 5. & $\begin{array}{l}\text { Simulasi } \\
\text { penilaian }\end{array}$ & $\begin{array}{l}\text { Simulasi penilaian } \\
\text { digunakan untuk } \\
\text { mengetahui gambaran nilai } \\
\text { yang akan diperoleh saat } \\
\text { melakukan pengumpulan } \\
\text { borang ke BAN-PT. }\end{array}$ & $\begin{array}{l}\text { Admin, Kaprodi, } \\
\text { Tim Penilaian } \\
\text { Akreditasi }\end{array}$ \\
\hline 6. & $\begin{array}{l}\text { Simulasi } \\
\text { input } \\
\text { penilaian }\end{array}$ & $\begin{array}{l}\text { Simulasi input penilaian } \\
\text { digunakan untuk pemilihan } \\
\text { nilai penilaian borang } \\
\text { program studi. }\end{array}$ & $\begin{array}{l}\text { Admin, Kaprodi, } \\
\text { Tim Penilaian } \\
\text { Akreditasi }\end{array}$ \\
\hline 7. & $\begin{array}{l}\text { What you see } \\
\text { is what you } \\
\text { get HTML } \\
\text { editor }\end{array}$ & $\begin{array}{l}\text { WYSIWYG HTML editor } \\
\text { digunakan untuk } \\
\text { memasukkan data yang } \\
\text { berupa informasi materi } \\
\text { borang. }\end{array}$ & $\begin{array}{l}\text { Admin, Kaprodi, } \\
\text { Tim Pengumpul } \\
\text { Data Akreditasi } \\
\text { Standar 5, Tim } \\
\text { Pengumpul Data } \\
\text { Akreditasi }\end{array}$ \\
\hline
\end{tabular}

Pada Gambar 8. Diilustrasikan alur dalam proses untuk melakukan upload dokumen. Pada Gambar 9 diilustrasikan alur dalam proses untuk melakukan simulasi penilaian akreditasi standar 5. User memanggil fungsi simulasipenilaian dan get_data untuk menampilkan halaman simulasi penilaian standar 5. Selanjutnya memanggil fungsi simpan dan insertNilai untuk menampilkan halaman simulasi penilaian standar 5. Pada Gambar 10 diilustrasikan alur dalam proses untuk melakukan pembagian tugas pada masingmasing anggota tim akreditasi. User memanggil fungsi index dan get_all_tim_akreditasi untuk menampilkan halaman daftar tugas anggota tim akreditasi. Selanjutnya, memanggil fungsi edittugas dan edit_tugas_user_akreditasi untuk menyimpan deskripsi tugas yang dimasukkan.

\section{Entity Relationship Diagram (ERD)}

ERD merupakan diagram yang berguna untuk menjelaskan hubungan antar data yang ada pada basis data. Satu tabel yang ada pada basis data mewakili satu entitas data. Pada ERD digambarkan entitas data serta atribut pada setiap entitas. Berikut adalah ERD untuk aplikasi pengelolaan dan penilaian akreditasi. 


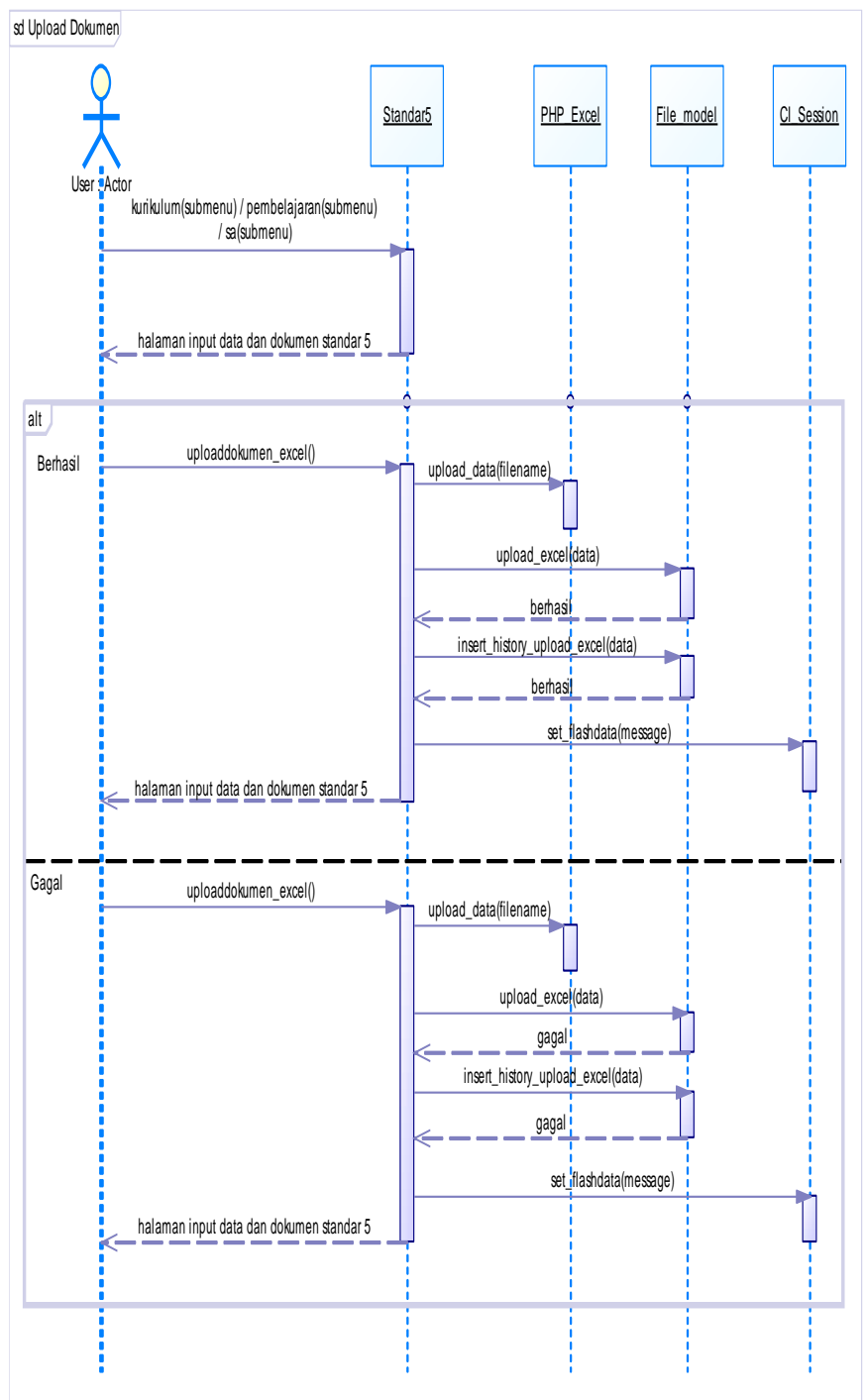

Gambar 8. Sequence Diagram Upload Dokumen

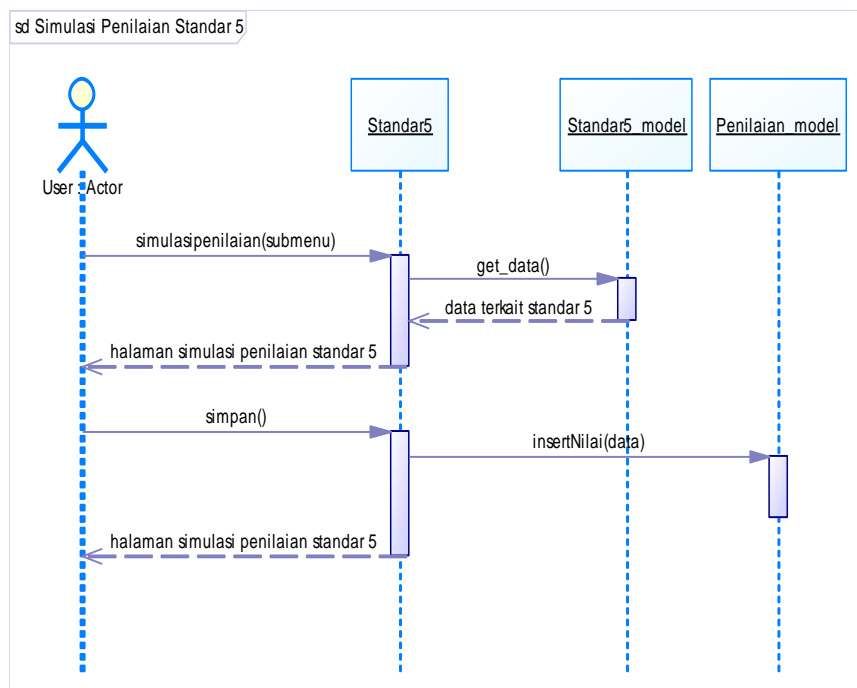

Gambar 9. Sequence Diagram Simulasi Penilaian Akreditasi Standar 5 sd Pembagian Tugas

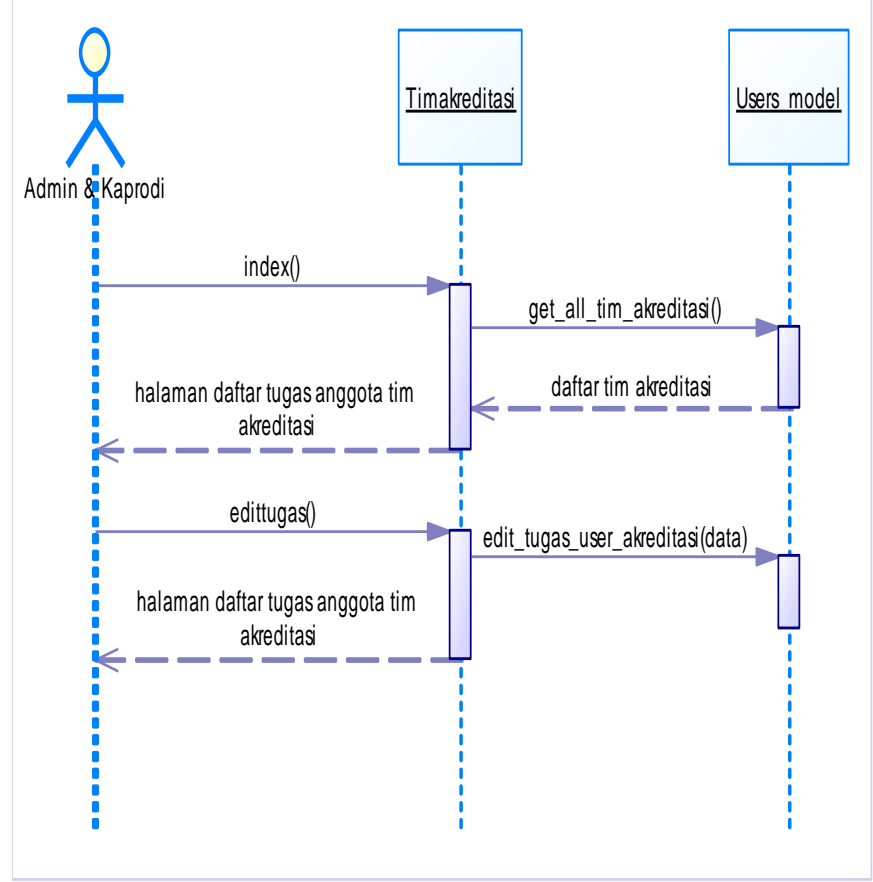

Gambar 10. Sequence Diagram Pembagian Tugas

\section{KESIMPULAN}

Berdasarkan penelitian terkait pembuatan rancang bangun aplikasi persiapan akreditasi yang telah dilakukan, dapat disimpulkan bahwa aplikasi akreditasi dibuat untuk mempermudah tim pengumpul data akreditasi dalam mempersiapkan data dan dokumen akreditasi. Fungsi-fungsi pada aplikasi persiapan akreditasi yaitu:

1. Pengelolaan tim akreditasi, yaitu pembagian tugas anggota tim akreditasi

2. Pengelolaan data dan dokumen pendukung borang akreditasi, antara lain:

a. Input atau edit data berupa informasi subjektif menggunakan CKEditor.

b. Upload data dari dokumen excel menggunakan template yang disediakan dan disimpan dalam basis data menggunakan library PHP Excel untuk pengambilan datanya.

c. Download file pdf untuk subbab akreditasi input data yang berupa informasi subjektif.

d. Daftar riwayat dokumen Excel yang sudah disimpan dalam sistem dapat diunduh.

e. Unduh atau hapus dokumen pendukung akreditasi yang sudah di upload.

3. Pengelolaan simulasi penilaian butir akreditasi

Dari hasil perancangan aplikasi yang dilakukan pada penelitian ini diperoleh peningkatan efisiensi sebesar $54 \%$ yang didapat dari jumlah aktivitas dari proses bisnis akreditasi standar 5 yang menggunakan aplikasi yaitu sebanyak 6 aktivitas, dibagi dengan jumlah total aktivitas sebanyak 11 aktivitas. Selain peningkatan efisiensi, dengan menggunakan aplikasi ini dicapai peningkatan efektivitas sebesar $34 \%$ yang didapat dari jumlah penilaian otomatis yang dilakukan oleh sistem sebanyak 9 penilaian dibagi dengan 
jumlah seluruh penilaian komponen akreditasi standar 5 sebanyak 26 penilaian. Dari hasil penelitian ini diharapkan dapat dilanjutkan ketahap selanjutnya yaitu pembuatan aplikasi. Perancangan yang dilakukan pada penelitian ini menjadi dasar untuk mengembangkan sistem informasi persiapan akreditasi secara utuh untuk seluruh standar penilaian yang ada. Adapun saran untuk pengembangan aplikasi selanjutnya antara lain menambahkan fitur sebagai berikut:
1. Fitur atau modul untuk evaluasi diri dan borang fakultas sehingga aplikasi tersebut menjadi lebih lengkap.

2. Fitur notifikasi untuk segala perubahan data dan dokumen pendukung serta hasil simulasi penilaian

3. Tugas anggota tim akreditasi dikirim ke email anggota akreditasi.

4. Fitur progress pekerjaan untuk setiap anggota tim akreditasi.

5. Fitur riwayat perubahan dokumen pada aplikasi ini.

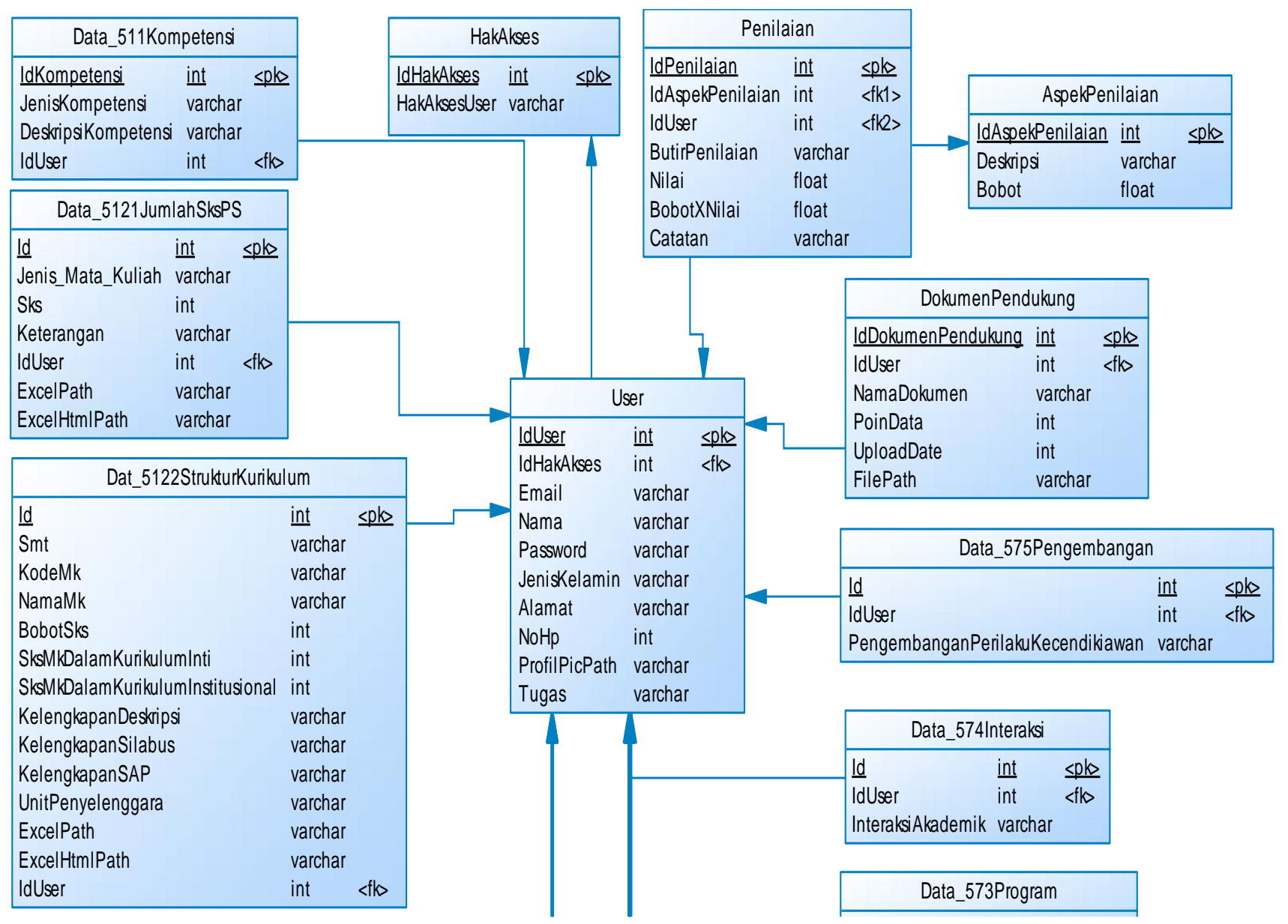

Gambar 12. Entity Relationship Diagram (ERD)

\section{DAFTAR PUSTAKA}

[1] Kemenristekdikti. 2016. PERMENRISTEKDIKTI NO. 32 TAHUN 2016-AKREDITASI PROGRAM STUDI DAN PERGURUAN TINGGI. Jakarta: Kemenristekdikti

[2] BAN-PT. 2008. Buku II Standar dan Prosedur Akredetasi Program Studi Sarjana. Jakarta: BAN-PT

[3] Fauzi, A. (2012). Perancangan Perangkat Lunak Borang Akreditasi Program Studi. Fakultas Ilmu Komputer Universitas Singaperbangsa Karawang

[4] Faturrahman, Sholiq, \& Muqtadiroh, F. A. (2013). Rancang Bangun Perangkat Lunak Sistem Kemahasiswaan dan Alumni untuk Pengembangan
Sistem Informasi Terintegrasi Sesuai Kebutuhan Pengisian Borang Akreditasi BAN-PT pada Jurusan Sistem Informasi ITS. JURNAL TEKNIK POMITS, 1-5.

[5] Saputro, F. C., Anggraeni, W., \& Mukhlason, A. 2012. Pembuatan Dashboard Berbasis Web Sebagai Sarana Evaluasi Diri Berkala untuk Persiapan Penilaian Akreditasi Berdasarkan Standar Badan Akreditasi Nasional Perguruan Tinggi. JURNAL TEKNIK ITS Vol. 1, 397-402.

[6] Alshamrani, A., \& Bahattab, A. 2015. A Comparison Between Three SDLC Models Waterfall Model, Spiral Model, and Incremental/Iterative Model. International Journal of Computer Science Issues, 106-111. 
[7] Stotts, D. (2016). Class Diagrams. Retrieved from Department of Computer Science University of North Carolina at Chapel Hill: http://www.cs.unc.edu/ stotts/145/CRC/class.html

[8] Lee, S. (2012). Unified Modeling Language (UML) for Database Systems and Computer Applications. International Journal of Database Theory and Application, (pp. 157-64). 